\section{RMD Open}

Rheumatic \&

Musculoskeletal Diseases

\title{
Association between osteoarthritis and dyslipidaemia: a systematic literature review and meta-analysis
}

\author{
Pauline Baudart, ${ }^{1,2}$ Karine Louati, ${ }^{1,3,4}$ Christian Marcelli, ${ }^{2,5,6,7}$ \\ Francis Berenbaum, ${ }^{1,3,4,8}$ Jérémie Sellam ${ }^{1,3,4,8}$
}

To cite: Baudart P, Louati K, Marcelli C, et al. Association between osteoarthritis and dyslipidaemia: a systematic literature review and meta-analysis. RMD Open 2017;3:e000442. doi:10.1136/ rmdopen-2017-000442

- Prepublication history and additional material for this paper are available online. To view these files please visit the journal online (http://dx.doi. org/10.1136/rmdopen-2017000442).

Received 23 January 2017 Revised 21 April 2017 Accepted 24 April 2017

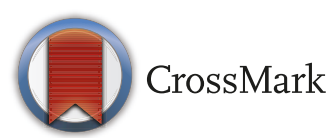

'Department of Rheumatology, Assistance Publique-Hôpitaux de Paris (AP-HP), Saint-Antoine Hospital, Paris, France ${ }^{2}$ Department of Rheumatology, Caen Teaching Hospital, Caen, France

${ }^{3}$ Inflammation-

Immunopathology-Biotherapy Department (DHU i2B), Paris,

France

${ }^{4}$ Sorbonne University, UPMC Univ Paris 06, Paris, France

${ }^{5}$ Normandy University, Caen,

France

${ }^{6}$ UNICAEN, COMETE, Caen,

France

${ }^{7}$ Inserm, U 1075 COMETE, Caen, France

${ }^{8}$ INSERM UMR_S938, Paris,

France

Correspondence to

Dr Jérémie Sellam;

jeremie.sellam@aphp.fr

\section{ABSTRACT}

Objectives We aimed to investigate the prevalence of dyslipidemia in patients with osteoarthritis $(O A)$ and whether $\mathrm{OA}$ and dyslipidemia are associated.

Methods We performed a systematic literature review and a meta-analysis, including cross-sectional, cohort and case-control studies, to assess the number of patients with $\mathrm{OA}$ and/or dyslipidemia. We calculated the mean $( \pm \mathrm{SD})$ prevalence of dyslipidemia in patients with and without $\mathrm{OA}$ and the risk of dyslipidemia $(\mathrm{OR}, 95 \% \mathrm{Cl})$ among patients with $0 A$.

Results From 605 articles screened, 48 were included in the analysis (describing 29 cross-sectional, 10 cohort and 9 case-control studies). The mean prevalence of dyslipidemia was $30.2 \% \pm 0.6 \%$ among 14843 patients with $\mathrm{OA}$ and $8.0 \% \pm 0.1 \%$ among 196168 without $\mathrm{OA}$. The risk of dyslipidemia was greater with than without $\mathrm{OA}$ overall (OR 1.98,95\% $\mathrm{Cl} 1.43$ to $2.75, \mathrm{p}<0.0001)$ and with knee $\mathrm{OA}$ (OR 2.27, 1.33 to $3.89, \mathrm{p}=0.003$ ) and hand $\mathrm{OA}$ (OR 2.12, 1.46 to 3.07 ), $p<0.0001$ ).

Conclusion The risk of dyslipidemia was twofold greater with than without $O A$, so lipid disturbances could be a risk factor for $0 A$. Such a result supports the individualisation of the metabolic syndrome-associated OA phenotype.

\section{INTRODUCTION}

Osteoarthritis (OA) is the most common joint disease and a major cause of pain and disability. It is currently considered a disease with multiple distinguishable phenotypes: post-traumatic, ageing-related, genetic and metabolic syndrome (MetS)-associated OA. ${ }^{1}$ Metabolic OA, the most commonly studied phenotype, is defined by the association between OA and MetS, associating obesity, hyperglycaemia with insulin resistance, dyslipidemia and hypertension. ${ }^{2}$ Metabolic OA mainly affects middle-aged people (45-65 years) and leads to knee, hand and generalised OA. The association between OA and MetS has been reported in several epidemiological studies. ${ }^{3} 4$ The pathophysiological link between both diseases could be chronic low-grade systemic inflammation occurring in both conditions. ${ }^{5}$

\section{Key messages}

What is already known about this subject?

- Metabolic disturbances such as obesity or diabetes mellitus are associated with osteoarthritis $(O A)$ but data about the link between $O A$ and lipid disturbances remain conflicting.

What does this study add?

- This is the first systematic review and meta-analysis demonstrating an association between $O A$ and dyslipidemia. This result reinforces the concept of the metabolic syndrome-associated OA phenotype.

How might this impact on clinical practice?

- This study emphasises the need to screen and manage cardiovascular comorbidities, especially lipid disturbances in patients with $0 \mathrm{~A}$ in clinical daily practice.

The association of $\mathrm{OA}$ with each MetS component has been investigated. ${ }^{6}$ Obesity and overweight are independently linked to hand OA, with a twofold increased risk. ${ }^{7}$ This association suggests the release of inflammatory mediators by adipose tissue adipokines. We recently reported an association between OA and diabetes mellitus, with a 1.46-fold increased risk of $\mathrm{OA}$ with diabetes mellitus and a 1.41-fold increased risk of diabetes mellitus with $\mathrm{OA}^{8}{ }^{8}$ The link between both pathologies could be explained by the action of pro-inflammatory cytokines and oxidative stress occurring in both diseases. ${ }^{9-12}$

The link between OA and the other components of MetS remains debated. Experimental studies have suggested that lipid disturbances could be involved in OA pathophysiology, ${ }^{13}$ but epidemiological studies revealed heterogeneous results.

With a systematic literature review and meta-analysis, we aimed to investigate the prevalence of dyslipidemia in patients with 


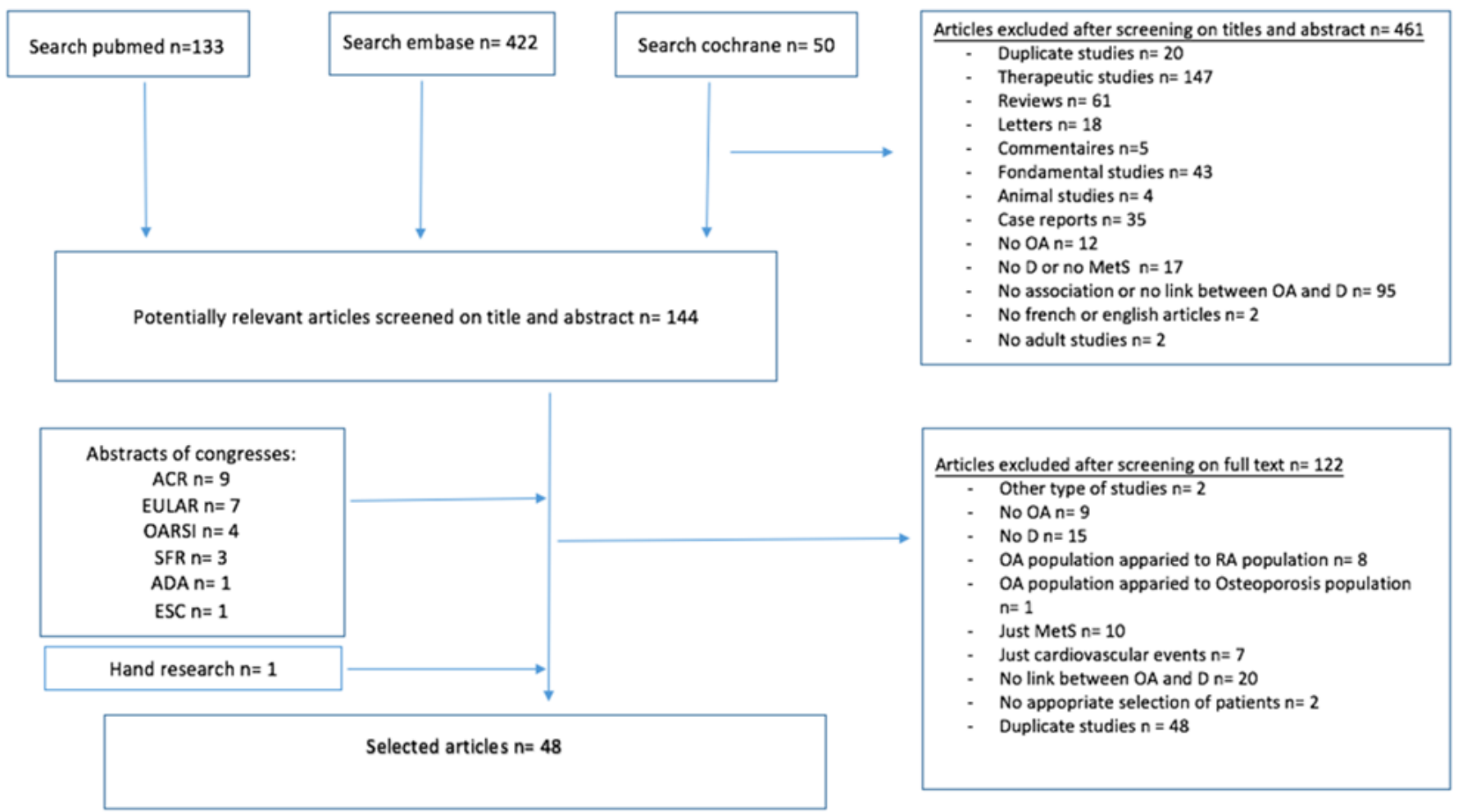

Leqend:OA: osteoarthritis, D: dyslipidemia, MetS: metabolic syndrome, RA: rheumatoid arthritis, ACR: congress of American College of rheumatology, EULAR: congress of European League Against rheumatism, OARSI: congress of Osteoarthritis Research Society International, SFR: congress of Société Française de Rhumatologie, ADA: congress of American Diabetes Association, ESC: congress of European Association for the Study of Diabetes

Figure 1 Flow chart of articles in the study

$\mathrm{OA}$ and assess whether $\mathrm{OA}$ and dyslipidemia are associated.

\section{METHODS}

The systematic review was registered on PROSPERO (CRD: 42016037290).

\section{Literature search}

We performed a systematic search of articles in MEDLINE via PubMed, EMBASE and the Cochrane library. The keywords used for the PubMed search were (('Dyslipidemias' [Mesh] OR 'Hypertriglyceridemia' [Mesh]) OR 'Hypercholesterolemia'[Mesh]) OR 'HDL'[All Fields] OR 'LDL' [All Fields] OR 'Triglycerides' [All Fields] OR 'Hyperlipidemias'[Mesh]) OR 'Cholesterol'[Mesh] OR 'Metabolic Syndrome X'[Mesh] AND 'Osteoarthritis'[Mesh] AND ('humans'[MeSH Terms] AND (English[lang] OR French[lang])). No time limit was set for publication date, and articles published up to 1 January 2016 were searched. We also searched the abstracts from international meetings of the American College of Rheumatology (ACR), European League Against Rheumatism, Société Française de Rhumatologie, European Society of Cardiology, Endocrine Society's Annual Meeting and European Congress of Endocrinology.

\section{Study selection}

We selected articles published in English or French that described observational studies of adults $(>18$ years of age) with cohort, case-control and cross-sectional designs. Studies were included if they specified the number of patients with OA and dyslipidemia and/ or the prevalence or incidence of $\mathrm{OA}$ in patients with dyslipidemia and/or dyslipidemia in patients with $\mathrm{OA}$, and/or the mean values of parameters of dyslipidemia in patients with and without $\mathrm{OA}$ and/or the existence or not of an association between $\mathrm{OA}$ and dyslipidemia. We excluded non-observational studies (therapeutic trials, reviews, letters and case reports). Articles that did not mention the number of patients with $\mathrm{OA}$ or dyslipidemia and those that did not evaluate the link between the two diseases were excluded. The selection of articles was based on titles and abstracts, then full texts.

\section{Data synthesis}

We extracted the following data: publication data (title of the article, first author, journal and publication date), study design (type of study, year(s) of inclusion, study quality score), population (total number of patients included, mean age and sex of patients), methodology of articles (the definition used for OA and dyslipidemia, OA location) and data needed for statistical analysis (number of patients with OA and/ or dyslipidemic patients; mean total cholesterol (TC), low-density lipoprotein (LDL), high-density lipoprotein (HDL) and triglyceride (TG) levels $(\mathrm{mg} / \mathrm{dL}$ or $\mathrm{mmol} / \mathrm{L})$; and number of patients receiving statins, 
Table 1 Description of the 48 articles studies selected for analysis

\begin{tabular}{|c|c|c|c|c|}
\hline \multicolumn{2}{|c|}{ Osteoarthritis population } & \multicolumn{3}{|c|}{ General population } \\
\hline Type of study & Author & Year & Author & Year \\
\hline \multirow[t]{17}{*}{ Cross-selectional } & Stürmer et $a l^{25}$ & 1998 & Davis et $a l^{26}$ & 1988 \\
\hline & Racaza et al ${ }^{65}$ & 2012 & Han et $a l^{27}$ & 2013 \\
\hline & Erb et $a l^{66}$ & 2004 & Dahaghin et $a l^{41}$ & 2007 \\
\hline & Eymard et $\left.a\right|^{28}$ & 2015 & Haugen et $a l^{42}$ & 2015 \\
\hline & Shea et $a l^{29}$ & 2015 & Inoue et $\left.a\right|^{30}$ & 2011 \\
\hline & Salamon et $a l^{50}$ & 2015 & Cemeroglu et $a l^{22}$ & 2014 \\
\hline & Abourazzak et al ${ }^{20}$ & 2015 & Meek et $a l^{51}$ & 2014 \\
\hline & Juge et $a l^{17 *}$ & 2015 & Al-Arfaj ${ }^{31}$ & 2003 \\
\hline & Rollefstad et $\left.a\right|^{23 *}$ & 2014 & Suri et $a l^{48}$ & 2010 \\
\hline & Saunders et $a l^{53 *}$ & 2013 & Puenpatom et al ${ }^{4}$ & 2009 \\
\hline & Nuñez et $\left.a\right|^{32 *}$ & 2012 & Hart et $a l^{19}$ & 1995 \\
\hline & Shukurova et $a l^{67 *}$ & 2014 & Maddah et $a^{24}$ & 2015 \\
\hline & Salaru et $a l^{33 *}$ & 2013 & Engström et al ${ }^{34}$ & 2009 \\
\hline & Kemta Lekpa et $\left.a\right|^{35 *}$ & 2014 & Yoshimura et $a l^{3}$ & 2012 \\
\hline & Niu et $a l^{36 *}$ & 2015 & Nielen et $a l^{54}$ & 2012 \\
\hline & Haugen et $a l^{43 *}$ & 2013 & Marshall et $a l^{44}$ & 2015 \\
\hline & Courties et $a l^{45 *}$ & 2014 & Hussain et $a l^{37}$ & 2014 \\
\hline \multirow[t]{3}{*}{ Cohort } & Gandhi et $a l^{49}$ & 2014 & Sowers et $a l^{21}$ & 2009 \\
\hline & Laires et $\left.a\right|^{38 *}$ & 2015 & Massengale et al ${ }^{46}$ & 2012 \\
\hline & Thelier-Deloison et $a l^{15 *}$ & 2012 & & \\
\hline \multirow[t]{9}{*}{ Case-control } & Soran et $a l^{16}$ & 2008 & & \\
\hline & Cheras et $a 1^{18}$ & 1997 & & \\
\hline & Mishra et $a l^{39}$ & 2012 & & \\
\hline & Oliviero et $a l^{52}$ & 2012 & & \\
\hline & Addimanda et $a l^{47}$ & 2012 & & \\
\hline & Philbin et $a l^{55}$ & 1996 & & \\
\hline & Irshad et $\left.a\right|^{56}$ & 2014 & & \\
\hline & Zayed et $a l^{40}$ & 2013 & & \\
\hline & Cheng et $a l^{57 *}$ & 2013 & & \\
\hline
\end{tabular}

${ }^{*}$ Data from a congress.

number with MetS and number with obesity or mean body mass index (BMI) in $\mathrm{kg} / \mathrm{cm}^{2}$ ). The quality of the study was estimated by using the Strengthening the Reporting of Observational Studies in Epidemiology (STROBE) scale, the score expressed in percentage of positive answers in relation to the number of items selected. ${ }^{14}$

\section{Statistical analysis}

First, we performed a descriptive analysis of the prevalence of dyslipidemia in patients with and without OA and used the number of patients with dyslipidemia and total number with and without OA. To estimate this prevalence from cohort longitudinal prospective studies, we used baseline data. Prevalence was expressed as mean \pm SD Second, we calculated the mean TC, LDL, HDL and TG levels in patients with and without OA.
Third, for studies examining an association between OA and dyslipidemia, we calculated the risk of dyslipidemia with OA by estimating the overall OR with $95 \%$ CIs. The data were extracted from studies examining the number of dyslipidemic patients with and without OA. We used Revman V.5.3 for the meta-analysis with a fixed-effects model. Heterogeneity was assessed by the $\mathrm{I}^{2}$ index; with $\mathrm{I}^{2}>50 \%$ (high heterogeneity), we used a random-effects model, and with $\mathrm{I}^{2}<50 \%$ (low heterogeneity), we used a fixed-effects model. With strong heterogeneity, we used a randomised-effects analysis. To investigate potential publication bias, we have performed the funnel plot. The association was considered positive with $\mathrm{OR}>1$, and the result was considered statistically significant with $\mathrm{p} \leq 0.05$. We performed sensitivity and subgroup analyses. 


\section{RESULTS}

\section{Characteristics of studies included}

The selection of articles is reported in the flow chart (figure 1). We identified 605 publications; 48 articles (including 13 abstracts) from 43 studies were included (2 articles from the SEKOIA study, 4 from the FRAMINGHAM study and 2 from the National Health and Nutrition Examination Survey III). One abstract ${ }^{15}$ was obtained from the EMBASE database and not from screening congress abstracts. The 48 articles described 29 cross-sectional, 10 cohort and 9 case-control studies. Among them, 29 articles involved the OA population and 19 the general population (table 1). We did not find any studies based on a cohort of patients with dyslipidemia, which explains why the prevalence or relative risk of OA in patients with dyslipidemia was not calculated. Table 2 shows the definitions of $\mathrm{OA}$ and dyslipidemia in selected studies.

The median STROBE quality score was $69.1 \%$ (range $42 \%-91 \%$ ). Nine articles had a STROBE quality score $<60 \%$ (table 3 ).

In total, 30 articles assessed the association of $\mathrm{OA}$ and dyslipidemia, 30 assessed the prevalence of dyslipidemia among patients with $\mathrm{OA}$ and 22 assessed mean lipid level values among patients with OA (table 3).

\section{Patient characteristics}

This study involved 306044 patients. The mean age range was $39.0 \pm 4.7^{16}$ to $77.5 \pm 9.0$ years. ${ }^{17}$ The mean proportion of females was $53.2 \%$ (range $40.6 \%{ }^{18}$ to $\left.100 \%{ }^{19-22}\right)$. The localisation was the knee in 23 articles, ${ }^{3} 151619-2124-40$ hand in $9,{ }^{152241-47}$ generalised OA in $3,{ }^{253147}$ hip in $3,{ }^{253437}$ spine in $2^{4849}$ and shoulder in $1 .{ }^{17}$ MetS was reported in nine articles, ${ }^{402428} 3036404350$ the prevalence of MetS ranged from $5 \%^{24}$ to $97.5 \%{ }^{40}$ The prevalence of obesity ranged from $7.8 \%^{51}$ to $100 \%^{1540}$ and BMI from $22.3 \pm 2.7^{30}$ to $37.3 \pm 5.9 \mathrm{~g} / \mathrm{cm}^{2}$. ${ }^{40}$ Seven articles described the use of statin treatment (table 3 ).

\section{Prevalence of dyslipidemia among patients with and without OA (table 4)}

The mean prevalence of dyslipidemia was $30.2 \% \pm 0.6 \%$ among 14843 patients with $\mathrm{OA}$ and $8.0 \% \pm 0.1 \%$ among 196168 without OA. The mean prevalence with knee $\mathrm{OA}$ was $27.6 \% \pm 1.4 \%,{ }^{15} 20242528 \quad 30-353738$ hand OA $37.6 \% \pm 1.6 \%,{ }^{22} 43-47$ generalised OA $30.5 \% \pm 3.9 \%,{ }^{25} 3147$ hip OA $20 \% \pm 2.1 \%^{253437}$ and symptomatic OA was $21 \%{ }^{2844}$

\section{Mean lipid-level values with and without OA (table 4)}

The mean lipid-level values for patients with and without OA were for TC, $245 \pm 25.1$ and $233.1 \pm 17.5 \mathrm{mg} / \mathrm{dL}$; LDL, $126.5 \pm 20.7$ and $136.9 \pm 15.9 \mathrm{mg} / \mathrm{dL}$; HDL, $54.4 \pm 8.9$ and $53.1 \pm 7.5 \mathrm{mg} / \mathrm{dL}$; and TG, $137.3 \pm 80.3$ and $131 \pm 27.3 \mathrm{mg} /$ dL.

\section{Association between dyslipidemia and $\mathrm{OA}$}

Overall, 30 articles indicated the presence or the absence of an association between $\mathrm{OA}$ and dyslipidemia; 21 $(70 \%)$ showed a positive association between $\mathrm{OA}$ and dyslipidemia $^{3} 41518192123242530313940474852-57$; 12/18 articles $(67 \%)$ with STROBE score $>60 \%$ found a positive association. ${ }^{3418192124304748525455}$ In addition, 4/7 articles $^{19253147}$ that reported an OR adjusted on age and BMI found a positive association. Among the three with negative association findings after adjustment, two had a STROBE score $>60 \%$. $^{34} 37$

\section{Overall risk of dyslipidemia with $\mathrm{OA}$ : meta-analysis}

Among 204148 patients from 13 articles, ${ }^{4} 15222430313437474854-56$ the overall OR was 1.98 ( $95 \%$ CI 1.43 to $2.75, \mathrm{p}<0.0001 ; \mathrm{I}^{2}=94 \%$ ), evaluated by a random-effects model (figure 2 ).

\section{Risk of dyslipidemia with $0 A$ : sensitivity analyses}

To strengthen our results, we performed four sensitivity analyses. First, we removed the studies that did not use ACR criteria or Kellgren-Lawrence grading for OA diagnosis: among 2568 patients from the six remaining articles, ${ }^{22} 2430314756$ the risk of dyslipidemia was increased with than without OA (OR 2.64, 95\% CI 2.14 to 3.26, $\left.\mathrm{p}<0.00001, \mathrm{I}^{2}=0 \%\right)$. Second, we excluded studies with a STROBE score $<60 \%$ : among 203629 patients from the nine remaining articles, ${ }^{4} 2430343747485455$ the risk of dyslipidemia remained increased with than without OA (OR 1.63, 1.13 to 2.36, $\mathrm{p}=0.009, \mathrm{I}^{2}=95 \%$ ). Third, we excluded studies that specified the use of statin treatment because the definition of dyslipidemia in these studies was based on only lipid values and did not account for statin treatment. Among 41539 patients from the 10 remaining articles, ${ }^{4152430} 313437474856$ the risk of dyslipidemia remained increased with than without OA (overall OR $1.93,1.42$ to $2.61, \mathrm{p}<0.0001, \mathrm{I}^{2}=87 \%$ ). Fourth, we pooled the results of the articles that reported an age-adjusted and BMI-adjusted OR. Among 31764 patients, from the four articles, ${ }^{31} 343747$ there was no association between dyslipidemia and OA (OR 1.31, 95\% CI 0.88 to $1.95, \mathrm{p}<0.0001, \mathrm{I}^{2}=83 \%$ ).

\section{Risk of dyslipidemia with $\mathrm{OA}$ : subgroup analyses}

We performed a subgroup analysis by OA localisation. The increased risk of dyslipidemia with OA persisted with knee OA (among 26805 patients, OR 2.27, 1.33 to 3.89,

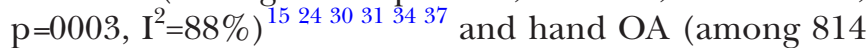
patients, OR 2.12, 1.46 to $\left.3.07, \mathrm{p}<0.0001, \mathrm{I}^{2}=0 \%\right)^{22}{ }^{47}$ but not hip OA (among 24934 patients, OR 0.86, 0.69 to 1.08, $\left.\mathrm{p}=0.18, \mathrm{I}^{2}=0 \%\right) .{ }^{34}{ }^{37}$

\section{DISCUSSION}

We investigated the potential association between $\mathrm{OA}$ and dyslipidemia with a systematic review and meta-analysis and found a $30 \%$ prevalence of dyslipidemia with OA, which seems much higher than in the non-OA population $(8.0 \%)$. Furthermore, the meta-analysis revealed an increased risk of dyslipidemia, by 1.98 , with than without $\mathrm{OA}$ and was observed with knee as well as hand OA.

The mean prevalence of dyslipidemia in hand OA was $37.6 \% \pm 1.6 \%$, much higher than the mean prevalence 
Table 2 Characteristics of the 48 included articles: definitions of osteoarthritis (OA) and dyslipidemia, outcomes and Strengthening the Reporting of Observational Studies in Epidemiology (STROBE) study quality

\begin{tabular}{|c|c|c|c|c|}
\hline Author & OA definition & Dyslipidemia definition & Outcome & $\begin{array}{l}\text { STROBE study } \\
\text { quality (\%) }\end{array}$ \\
\hline Stürmer et $\mathrm{al}^{25}$ & $\begin{array}{l}\text { Arthroplasty or } \\
\mathrm{KL} \geq 2\end{array}$ & $\begin{array}{l}\mathrm{TC} \geq 240 \mathrm{mg} / \mathrm{dL} \text { and/or } \\
\text { statin therapy }\end{array}$ & $\begin{array}{l}\text { MV in OA+ } \\
\text { Association of OA and } \\
\text { dyslipidemia }\end{array}$ & 53 \\
\hline Racaza et $a l^{65}$ & $\mathrm{ACR}$ or $\mathrm{Cq}$ and $\mathrm{Rx}$ & - & NPD in OA+ & 42 \\
\hline Erb et $a l^{66}$ & $\mathrm{Cq}$ and $\mathrm{Rx}$ & - & $\mathrm{MV}$ in $\mathrm{OA}_{+}$ & 50 \\
\hline Shea et $a l^{29}$ & $\mathrm{Cq}$ and $\mathrm{Rx}$ & - & $\begin{array}{l}\text { NPS in } \mathrm{OA}_{+} \\
\mathrm{MV} \text { in } \mathrm{OA}+\end{array}$ & 78 \\
\hline Salamon et $\left.a\right|^{50}$ & ACR & - & $\begin{array}{l}\text { NPD in } \mathrm{OA}_{+} \\
\mathrm{MV} \text { in } \mathrm{OA}+\end{array}$ & 72 \\
\hline Rollefstad et $a l^{23 *}$ & History of OA & - & $\begin{array}{l}\text { MV in OA+ and OA- } \\
\text { Association of OA and } \\
\text { dyslipidemia }\end{array}$ & NA \\
\hline Saunders et al ${ }^{53 *}$ & $\mathrm{KL}$ scale & $\mathrm{TC}>4 \mathrm{mmol} / \mathrm{L}$ & $\begin{array}{l}\text { NPD in OA+ } \\
\text { Association of MV and } \mathrm{KL} \text { scale }\end{array}$ & NA \\
\hline Nuñez et $\left.a\right|^{32 *}$ & - & Hypercholesterolemia (ND) & NPD in OA+ & NA \\
\hline Shukurova et $a l^{67 *}$ & - & Hypercholesterolemia (ND) & NPD in OA+ & NA \\
\hline Salaru et $a l^{33 *}$ & ACR & - & NPD in $\mathrm{OA}+$ & NA \\
\hline Kemta Lekpa et $a l^{35 *}$ & ACR & - & NPD in OA+ & NA \\
\hline Niu et $a l^{36 *}$ & $\begin{array}{l}\text { Arthroplasty or } \\
\mathrm{KL} \geq 2\end{array}$ & $\begin{array}{l}\mathrm{HDL}<40 \mathrm{mg} / \mathrm{dL} \text { in } \\
\mathrm{M} ;<50 \mathrm{mg} / \mathrm{dL} \text { in } \mathrm{W} \\
\mathrm{TG}>150 \mathrm{mg} / \mathrm{dL}\end{array}$ & $\begin{array}{l}\text { Association of OA and } \\
\text { dyslipidemia }\end{array}$ & NA \\
\hline Gandhi et al ${ }^{49}$ & $\mathrm{Cq}$ and $\mathrm{Rx}$ & $\begin{array}{l}\mathrm{HDL}<35 \mathrm{mg} / \mathrm{dL} \text { in } \\
\mathrm{M},<40 \mathrm{mg} / \mathrm{dL} \text { in } \mathrm{W} ; \\
\mathrm{TG} \geq 150 \mathrm{mg} / \mathrm{dL}\end{array}$ & NPD in $\mathrm{OA}+$ & 52 \\
\hline Laires et $\left.a\right|^{38 *}$ & - & - & NPD in OA+ & NA \\
\hline Thelier-Deloison et $a 1^{15 *}$ & History of OA & - & $\begin{array}{l}\text { NPD in OA+ and OA- } \\
\text { Association of OA and } \\
\text { dyslipidemia }\end{array}$ & NA \\
\hline Soran et al ${ }^{16}$ & $\mathrm{Cq}$ and $\mathrm{Rx}$ & - & $\begin{array}{l}\text { MV in OA+ and OA- } \\
\text { Association of OA and } \\
\text { dyslipidemia }\end{array}$ & 65 \\
\hline Cheras et $a l^{18}$ & $\mathrm{Cq}$ and $\mathrm{Rx}$ & - & $\begin{array}{l}\text { MV in OA+ and OA- } \\
\text { Association of OA and } \\
\text { dyslipidemia }\end{array}$ & 75 \\
\hline Mishra et $\left.a\right|^{39}$ & $\begin{array}{l}\text { KL scale } \\
\text { ACR }\end{array}$ & - & $\begin{array}{l}\text { MV in OA+ and OA- } \\
\text { Association of OA and } \\
\text { dyslipidemia }\end{array}$ & 58 \\
\hline Oliviero et $\left.a\right|^{52}$ & ACR & - & $\begin{array}{l}\text { MV in OA+ and OA- } \\
\text { Association OA and } \\
\text { dyslipidemia }\end{array}$ & 67 \\
\hline
\end{tabular}


Table 2 Continued

\begin{tabular}{|c|c|c|c|c|}
\hline Author & OA definition & Dyslipidemia definition & Outcome & $\begin{array}{l}\text { STROBE study } \\
\text { quality (\%) }\end{array}$ \\
\hline Addimanda et $\mathrm{al}{ }^{47}$ & $\begin{array}{l}\mathrm{Cq} \\
\mathrm{KL} \text { scale }\end{array}$ & $\begin{array}{l}\mathrm{LDL} \geq 130 \mathrm{mg} / \mathrm{dL} \text { and/ } \\
\text { or } \mathrm{CT} \geq 240 \mathrm{mg} / \mathrm{dL} \text { and/or } \\
\text { statin therapy }\end{array}$ & $\begin{array}{l}\text { NPD in OA+ and OA- } \\
\text { Association of OA and } \\
\text { dyslipidemia }\end{array}$ & 75 \\
\hline Philbin et $a l^{55}$ & $\begin{array}{l}\text { Questionnaire } \\
\text { Radiological } \\
\text { Danielson scale }\end{array}$ & $\begin{array}{l}\mathrm{LDL} \geq 160 \mathrm{mg} / \mathrm{dL} \text { and/or } \\
\mathrm{HDL} \leq 35 \mathrm{mg} / \mathrm{dL}\end{array}$ & $\begin{array}{l}\text { NPD in OA+ and OA- } \\
\text { NPS in OA+ and OA- } \\
\text { Association of OA and } \\
\text { dyslipidemia } \\
\text { MV in OA+ and OA- }\end{array}$ & 73 \\
\hline Irshad et $\left.a\right|^{56}$ & $\mathrm{KL}$ scale & $\begin{array}{l}\mathrm{TC} \geq 200 \mathrm{mg} / \mathrm{dL} \text { and } / \mathrm{or} \\
\mathrm{TG} \geq 150 \mathrm{mg} / \mathrm{dL}\end{array}$ & $\begin{array}{l}\text { NPD in OA+ and OA- } \\
\text { Association of OA and } \\
\text { dyslipidemia } \\
\text { MV in OA+ and OA- }\end{array}$ & 47 \\
\hline Cheng et $a l^{57 *}$ & - & - & $\begin{array}{l}\text { Association of OA and } \\
\text { dyslipidemia }\end{array}$ & NA \\
\hline Davis et $\mathrm{al}^{26}$ & $\mathrm{Rx}$ & - & $\begin{array}{l}\text { MV in OA+ and OA- } \\
\text { Association of OA and } \\
\text { dyslipidemia }\end{array}$ & 67 \\
\hline Han et $a l^{27}$ & $\begin{array}{l}\text { History of OA by } \\
\text { physician }\end{array}$ & $\begin{array}{l}\mathrm{HDL}<40 \mathrm{mg} / \mathrm{dL} \text { in } \\
\mathrm{M},<50 \mathrm{mg} / \mathrm{dL} \text { in } \mathrm{W} ; \\
\mathrm{TG} \geq 150 \mathrm{mg} / \mathrm{dL}\end{array}$ & $\begin{array}{l}\mathrm{MV} \text { in } \mathrm{OA}+\text { and } \mathrm{OA}- \\
\text { Association of } \mathrm{OA} \text { and } \\
\text { dyslipidemia }\end{array}$ & 84 \\
\hline Dahaghin et al ${ }^{41}$ & $\mathrm{KL} \geq 2, \mathrm{ACR}, \mathrm{Cq}$ & - & $\begin{array}{l}\text { MV in OA+ and OA- } \\
\text { Association of OA and } \\
\text { dyslipidemia }\end{array}$ & 69 \\
\hline Cemeroglu et $a l^{22}$ & $\begin{array}{l}\geq 3 \text { articulations } \\
\text { with } \mathrm{KL} \geq 2\end{array}$ & $\begin{array}{l}\mathrm{TC}>200 \mathrm{mg} / \mathrm{dL} \\
\mathrm{LDL}>100 \mathrm{mg} / \mathrm{dL} \\
\mathrm{HDL}<40 \mathrm{mg} / \mathrm{dL} \text { TG }>150 \mathrm{mg} / \\
\mathrm{dL}\end{array}$ & $\begin{array}{l}\text { NPD in OA+ and OA- } \\
\text { MV in OA+ and OA- } \\
\text { NPS in OA+ and OA- } \\
\text { Association of OA and } \\
\text { dyslipidemia }\end{array}$ & 59 \\
\hline Meek et $a l^{51}$ & Codes & - & $\begin{array}{l}\text { MV in OA+ } \\
\text { NPS in OA+ }\end{array}$ & 78 \\
\hline Al-Arfaj ${ }^{31}$ & $K L \geq 2$ & $\mathrm{TC} \geq 220 \mathrm{mg} / \mathrm{dL}$ & $\begin{array}{l}\text { NPD in OA+ and OA- } \\
\text { Association of OA and } \\
\text { dyslipidemia }\end{array}$ & 50 \\
\hline Suri et $a l^{48}$ & $\begin{array}{l}\text { Pathria and } \\
\text { Weishaupt scale }\end{array}$ & $\mathrm{TC} \geq 240 \mathrm{mg} / \mathrm{dL}$ & $\begin{array}{l}\text { NPD in OA+ and OA- } \\
\text { Association of OA and } \\
\text { dyslipidemia }\end{array}$ & 72 \\
\hline Puenpatom et al ${ }^{4}$ & $\begin{array}{l}\text { Codes } \\
\text { Rx } \\
\text { History of OA by } \\
\text { physician }\end{array}$ & $\begin{array}{l}\text { Codes or } \mathrm{HDL}<40 \mathrm{mg} / \mathrm{dL} \\
\text { in } \mathrm{M},<50 \mathrm{mg} / \mathrm{dL} \text { in } \mathrm{W} \text {; or } \\
\mathrm{TG} \geq 150 \mathrm{mg} / \mathrm{dL}\end{array}$ & $\begin{array}{l}\text { NPD in OA+ and OA- } \\
\text { Association of OA and } \\
\text { dyslipidemia }\end{array}$ & 69 \\
\hline Hart et al ${ }^{19}$ & $\mathrm{KL} \geq 2$ & - & $\begin{array}{l}\text { Association of OA and } \\
\text { dyslipidemia }\end{array}$ & 78 \\
\hline
\end{tabular}

Continued 
Table 2 Continued

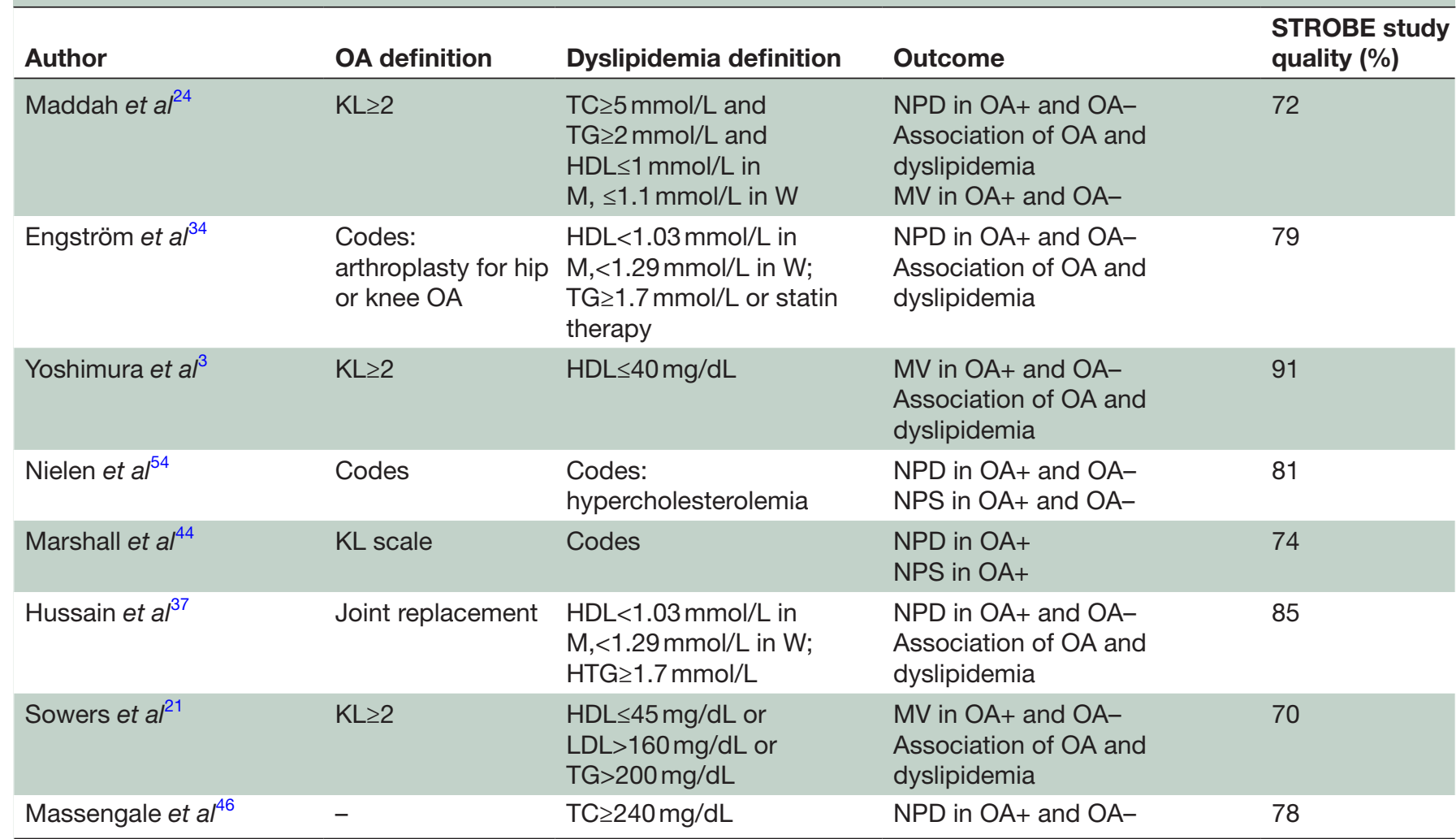

ACR, American College of Rheumatology; Cq, clinical; HDL, high-density lipoprotein; HTG, hypertriglyceridemia; KL, Kellgren and Lawrence; LDL, low-density lipoprotein; M, men; MV, mean values of lipid profile; NA, if the data were issued only from congress; ND, not defined; NPD, number of patients with dyslipidemia; NPS, number of patients with statin therapy; OA+, patients with osteoarthritis; OA-, patients without osteoarthritis; Rx, radiography; TC, total cholesterol; TG, triglycerides; W, women.

*Data from a congress.

of $30.2 \% \pm 0.6 \%$ with $\mathrm{OA}$ overall. Moreover, the risk of dyslipidemia was increased twofold with hand OA (OR $2.12,95 \%$ CI 1.46 to 3.07$)$. These results again confirm the systemic metabolic component of hand OA, as recently reported in the NEO study. ${ }^{58}$ The pathophysiological link between hand OA and MetS might be explained by the action of the adipose-tissue source of proinflammatory cytokines and the action of visceral fat. ${ }^{58}$

Hip OA, defined by joint replacement, was not associated with dyslipidemia possibly because of a selection bias of patients: cardiovascular comorbidities often associated with dyslipidemia might have restricted the indication for surgery due to the perioperative period. Furthermore, mechanical stress is more involved than metabolic stress in this joint.

For knee OA, the mean prevalence of dyslipidemia was $27.6 \% \pm 1.4 \%$ and the association between knee OA and dyslipidemia was confirmed with increased risk of dyslipidemia (OR 2.27, 95\% CI 1.33 to 3.89). The association between knee $\mathrm{OA}$ and MetS is sometimes conflicting. Han et $a l,{ }^{27}$ Inoue et $a l,{ }^{30}$ and Hussain $e t a l^{37}$ did not find any positive association possibly because of different OA definitions. A recent study showed that the most important risk factor of knee OA was mechanical stress (before and after adjustment for metabolic factors), which limits the identification of a systemic metabolic component in knee OA.

Our meta-analysis has some limitations. The heterogeneity between studies was high, probably because of differences in OA localisations, definition of $\mathrm{OA}$ and dyslipidemia, statin therapy could not have been taken into account, and types and quality of studies. Dyslipidemia referred to lipid abnormalities such as hypercholesterolemia, low HDL level, high LDL level or hypertriglyceridemia. Because of the different definitions of dyslipidemia, we chose to define dyslipidemia first by high LDL level, then low HDL level, then hypercholesterolemia and hypertriglyceridemia. To counteract this heterogeneity, we performed sensitivity analyses to check whether the association between $\mathrm{OA}$ and dyslipidemia persisted after removing studies with poor methodology and found that the association persisted in all sensitivity analyses. Moreover, the heterogeneity of the studies was assessed by the $\mathrm{I}^{2}$ index and we adapted the method to its value. The results of the meta-analysis are not modified by removing the most heterogeneous studies (data not shown). We were not able to integrate confounding factors such as age, BMI, HTA, smoking and physical activity in the overall statistical analysis. Obesity is a major risk 
Table 3 Characteristics of the population on the 48 included articles: number, age, gender, overweight proportion

\begin{tabular}{|c|c|c|c|c|}
\hline Author & $\begin{array}{l}\text { Sample size ( } N=\text { number of } \\
\text { total patients; } n=\text { number } \\
\text { of patients with OA) }\end{array}$ & $\begin{array}{l}\text { Mean age (years) } \\
\text { in } O A+\text { and } O A- \\
\text { patients }\end{array}$ & $\begin{array}{l}\text { Gender in OA+ } \\
\text { and OA- patients } \\
(\% \text { of } F)\end{array}$ & $\begin{array}{l}\text { Overweight proportion } \\
(\%) \text { or BMI }\left(\mathrm{kg} / \mathrm{m}^{2}\right) \text { in } \\
\text { OA+ and OA- }\end{array}$ \\
\hline Stürmer et $a l^{25}$ & $n=809$ & - & $\mathrm{OA}+\mathrm{F}: 62.3 \%$ & - \\
\hline Racaza et a/ ${ }^{65}$ & $n=859$ & $O A+: 62.9$ & OA+: F: 74.5\% & - \\
\hline Erb et $a l^{66}$ & $\begin{array}{l}\mathrm{N}=250 \\
\mathrm{n}=64\end{array}$ & $\mathrm{OA}+: 57.3 \pm 10.1$ & $\mathrm{OA}+\mathrm{F}: 62.5 \%$ & $\mathrm{OA}+: 30.9 \pm 7.6 \mathrm{~kg} / \mathrm{m}^{2}$ \\
\hline Eymard et $a l^{28}$ & $n=559$ & $O A+: 62.8$ & OA+: F: 70.1\% & \\
\hline Shea et $\left.a\right|^{29}$ & $n=791$ & $\mathrm{OA}+: 74.25 \pm 4.5$ & $\mathrm{OA}+\mathrm{F}: 62.3 \%$ & $\mathrm{OA}+: 27.28 \mathrm{~kg} / \mathrm{m}^{2}$ \\
\hline Salamon et $\left.a\right|^{50}$ & $\begin{array}{l}\mathrm{N}=927 \\
\mathrm{n}=344\end{array}$ & - & OA+: F: 83.4\% & $\mathrm{OA}+: 29.5 \mathrm{~kg} / \mathrm{m}^{2}$ \\
\hline Abourazzak et $a^{20}$ & $n=130$ & $\mathrm{OA}+: 56.7 \pm 8.1$ & OA+: F: $100 \%$ & $\mathrm{OA}+: 32.54 \pm 2.9 \mathrm{~kg} / \mathrm{m}^{2}$ \\
\hline Juge et $a l^{17}$ * & $\mathrm{n}=147$ & $\mathrm{OA}+: 75.8 \pm 10$ & OA+: F: 68.7\% & $\mathrm{OA}+: 27.2 \mathrm{~kg} / \mathrm{m}^{2}$ \\
\hline Rollefstad et $a l^{23}$ * & $\begin{array}{l}\mathrm{N}=626 \\
\mathrm{n}=469\end{array}$ & $\begin{array}{l}\mathrm{OA}+:=64.1 \pm 8.6 \\
\mathrm{OA}-: 63.3 \pm 9.3\end{array}$ & $\begin{array}{l}\text { OA+: F: } 73.1 \% \\
\text { OA-: F: } 58 \%\end{array}$ & - \\
\hline Saunders et $a l^{53 *}$ & $\mathrm{n}=57$ & - & - & - \\
\hline Nuñez et $\left.a\right|^{32}$ * & $n=260$ & $\mathrm{OA}+:=9.8 \pm 8$ & OA+: F: $79.2 \%$ & - \\
\hline Shukurova et $a l^{67}$ * & $n=1243$ & $\mathrm{OA}+: 56.1 \pm 7.9$ & - & OA+: $61.6 \%$ of OP \\
\hline Salaru et $a l^{33}$ * & $\mathrm{n}=61$ & $\mathrm{OA}+: 64.9 \pm 2.7$ & OA+: F: $77 \%$ & $\mathrm{OA}+\mathrm{t} 60.6 \%$ of $\mathrm{OP}$ \\
\hline Kemta Lekpa et al ${ }^{35}$ * & $n=148$ & OA+: $57 \pm 10.6$ & OA+: F: $75 \%$ & $\begin{array}{l}\mathrm{OA}+53 \% \text { of } \mathrm{OP} \\
30.8 \pm 5.6 \mathrm{~kg} / \mathrm{m}^{2}\end{array}$ \\
\hline Niu et $a l^{36}$ * & $n=1091$ & OA+: 62 & OA+: F: 55.5\% & - \\
\hline Haugen et $a l^{43}$ * & $\mathrm{n}=748$ & $O A+: 58.1$ & - & $\mathrm{OA}+65.7 \%$ of $\mathrm{OP}$ \\
\hline Courties et $a l^{45}$ * & $\mathrm{n}=869$ & $O A+: 54 \pm 7$ & OA+: $F: 72 \%$ & - \\
\hline Gandhi et a ${ }^{49}$ & $n=1502$ & $O A+: 55.3 \pm 15.5$ & OA+: F: 48.8\% & $\mathrm{OA}+: 27.3 \mathrm{~kg} / \mathrm{m}^{2}$ \\
\hline Laires et $\left.a\right|^{38 \text { * }}$ & $n=197$ & $O A+: 67 \pm 8.6$ & OA+: F: $79.2 \%$ & - \\
\hline Thelier-Deloison et al ${ }^{15}$ * & $\begin{array}{l}n=112 \\
n=26\end{array}$ & - & - & $\mathrm{OA}+: 100 \%$ of $\mathrm{OP}$ \\
\hline Soran et $a 1^{16}$ & $\begin{array}{l}\mathrm{N}=66 \\
\mathrm{n}=36\end{array}$ & $\begin{array}{l}\mathrm{OA}+: 40.9 \pm 2.5 \\
\mathrm{OA}-:=39 \pm 4.7\end{array}$ & $\begin{array}{l}\text { OA+: F: } 72.2 \% \\
\text { OA-: } F: 66.7 \%\end{array}$ & $\begin{array}{l}\mathrm{OA}+: 29.9 \pm 3.3 \mathrm{~kg} / \mathrm{m}^{2} \\
\mathrm{OA}-: 27.6 \pm 3.8 \mathrm{~kg} / \mathrm{m}^{2}\end{array}$ \\
\hline Cheras et $a l^{18}$ & $\begin{array}{l}\mathrm{N}=96 \\
\mathrm{n}=44\end{array}$ & $\begin{array}{l}\mathrm{OA}+: 69 \pm 9 \\
\mathrm{OA}-: 68 \pm 7\end{array}$ & $\begin{array}{l}\text { OA+: F } 40.9 \% \\
\text { OA-: F 40.4\% }\end{array}$ & $\begin{array}{l}\mathrm{OA}+: 25.8 \mathrm{~kg} / \mathrm{m}^{2} \\
\mathrm{OA}-: 24.8 \mathrm{~kg} / \mathrm{m}_{2}\end{array}$ \\
\hline Mishra et $\left.a\right|^{39}$ & $\begin{array}{l}\mathrm{N}=100 \\
\mathrm{n}=28\end{array}$ & $\begin{array}{l}\mathrm{OA}+:=49.1 \pm 1.4 \\
\mathrm{OA}-: 49.6 \pm 1.3\end{array}$ & $\begin{array}{l}\text { OA+: M: F: } 71.4 \% \\
\text { OA-: M: F: } 69.4 \%\end{array}$ & $\begin{array}{l}\mathrm{OA}+: 23.4 \pm 0.6 \mathrm{~kg} / \mathrm{m}^{2} \\
\mathrm{OA}-: 22.9 \pm 0.6 \mathrm{~kg} / \mathrm{m}^{2}\end{array}$ \\
\hline Oliviero et $\left.a\right|^{52}$ & $\begin{array}{l}N=77 \\
n=16\end{array}$ & $\begin{array}{l}\text { OA+: } 54.7 \pm 11.5 \\
\text { OA-: - }\end{array}$ & $\begin{array}{l}\text { OA+: F: } 68.7 \% \\
\text { OA-: - }\end{array}$ & - \\
\hline Addimanda et $a l^{47}$ & $\begin{array}{l}\mathrm{N}=753 \\
\mathrm{n}=446\end{array}$ & $\begin{array}{l}\mathrm{OA}+:=6 \pm \pm 8 \\
\mathrm{OA}-: 63.9 \pm 9\end{array}$ & $\begin{array}{l}\text { OA+: } F: 92.8 \% \\
\text { OA- : F : } 97.4 \%\end{array}$ & $\begin{array}{l}\mathrm{OA}+: 25.1 \pm 3.8 \mathrm{~kg} / \mathrm{m}^{2} \\
\mathrm{OA}-: 24.9 \pm 3.9 \mathrm{~kg} / \mathrm{m}^{2}\end{array}$ \\
\hline Philbin et $\left.a\right|^{55}$ & $\begin{array}{l}\mathrm{N}=69 \\
\mathrm{n}=46\end{array}$ & $\begin{array}{l}\text { OA+: } 65.8 \pm 9.3 \\
\text { OA-: } 67.9 \pm 6.7\end{array}$ & $\begin{array}{l}\text { OA+: F: } 56.5 \% \\
\text { OA-: F: } 65.2 \%\end{array}$ & $\begin{array}{l}\mathrm{OA}+: 31.2 \pm 5.9 \mathrm{~kg} / \mathrm{m}^{2} \\
\mathrm{OA}-:=24.6 \pm 3.2 \mathrm{~kg} / \mathrm{m}^{2}\end{array}$ \\
\hline Irshad et $\left.a\right|^{56}$ & $\begin{array}{l}N=100 \\
n=50\end{array}$ & - & - & - \\
\hline Zayed et a $\left.\right|^{40}$ & $\begin{array}{l}\mathrm{N}=80 \\
\mathrm{n}=40\end{array}$ & $\begin{array}{l}\text { OA+: } 43.5 \pm 3.7 \\
\text { OA-: } 44.4 \pm 3.9\end{array}$ & $\begin{array}{l}\text { OA+: F: } 87.5 \% \\
\text { OA-: F: } 87.5 \%\end{array}$ & $\begin{array}{l}\mathrm{OA}+: 37.3 \pm 5.9 \mathrm{~kg} / \mathrm{m}^{2} \\
\mathrm{OA}-:=23.5 \pm 1.3 \mathrm{~kg} / \mathrm{m}^{2}\end{array}$ \\
\hline Cheng et $a l^{57}$ * & $\begin{array}{l}N=56607 \\
n=23530\end{array}$ & - & - & - \\
\hline Davis et $a^{26}$ & $\begin{array}{l}\mathrm{N}=3885 \\
\mathrm{n}=301\end{array}$ & - & - & - \\
\hline Han et $a l^{27}$ & $\begin{array}{l}\mathrm{N}=10839 \\
\mathrm{n}=270\end{array}$ & $\begin{array}{l}\mathrm{OA}+: 64.5 \pm 10.1 \\
\mathrm{OA}-:=53.2 \pm 11\end{array}$ & $\begin{array}{l}\text { OA+: F: } 84.8 \% \\
\text { OA-: F: } 50 \%\end{array}$ & - \\
\hline
\end{tabular}


Table 3 Continued

\begin{tabular}{|c|c|c|c|c|}
\hline Author & $\begin{array}{l}\text { Sample size }(\mathrm{N}=\text { number of } \\
\text { total patients; } \mathrm{n}=\text { number } \\
\text { of patients with OA) }\end{array}$ & $\begin{array}{l}\text { Mean age (years) } \\
\text { in } O A+\text { and } O A- \\
\text { patients }\end{array}$ & $\begin{array}{l}\text { Gender in OA+ } \\
\text { and OA- patients } \\
\text { ( } \% \text { of } F)\end{array}$ & $\begin{array}{l}\text { Overweight proportion } \\
(\%) \text { or BMI }\left(\mathrm{kg} / \mathrm{m}^{2}\right) \text { in } \\
\text { OA+ and OA- }\end{array}$ \\
\hline Dahaghin et $a /^{41}$ & $n=3585$ & - & - & $\mathrm{OA}+26.3 \pm 3.5 \mathrm{~kg} / \mathrm{m}^{2}$ \\
\hline Haugen et al ${ }^{42}$ & $\begin{array}{l}N=1348 \\
n=726\end{array}$ & - & - & - \\
\hline Inoue et $\left.a\right|^{30}$ & $\begin{array}{l}N=795 \\
n=251\end{array}$ & $\begin{array}{l}\text { OA+: } 66.3 \\
\text { OA-: } 55.5\end{array}$ & $\begin{array}{l}\text { OA+: F: } 79.3 \% \\
\text { OA-: } F: 54.7 \%\end{array}$ & $\begin{array}{l}\mathrm{OA}+: 23.8 \mathrm{~kg} / \mathrm{m}^{2} \\
\mathrm{OA}-: 22.8 \mathrm{~kg} / \mathrm{m}^{2}\end{array}$ \\
\hline Cemeroglu et $a l^{22}$ & $\begin{array}{l}\mathrm{N}=61 \\
\mathrm{n}=39\end{array}$ & - & $\begin{array}{l}\text { OA+: F: } 100 \% \\
\text { OA-: F: } 100 \%\end{array}$ & - \\
\hline Meek et $\left.a\right|^{51}$ & $\begin{array}{l}\mathrm{N}=858 \\
\mathrm{n}=206\end{array}$ & $\mathrm{OA}+: 59.2 \pm 11$ & OA+: F: $79.1 \%$ & - \\
\hline Al-Arfaj ${ }^{31}$ & $\begin{array}{l}\mathrm{N}=246 \\
\mathrm{n}=122\end{array}$ & - & - & - \\
\hline Suri et $a l^{48}$ & $\begin{array}{l}\mathrm{N}=441 \\
\mathrm{n}=310\end{array}$ & $\begin{array}{l}\mathrm{OA}+: 57.8 \pm 10.6 \\
\mathrm{OA}-:=46.7 \pm 9.7\end{array}$ & $\begin{array}{l}\text { OA+: F: } 49 \% \\
\text { OA-: F: } 39 \%\end{array}$ & - \\
\hline Puenpatom et al ${ }^{4}$ & $\begin{array}{l}\mathrm{N}=7714 \\
\mathrm{n}=975\end{array}$ & $\begin{array}{l}\mathrm{OA}+: 69.6 \\
\mathrm{OA}-: 41.3\end{array}$ & $\begin{array}{l}\text { OA+: F: } 61.3 \% \\
\text { OA-: F: } 51.3 \%\end{array}$ & $\begin{array}{l}\mathrm{OA}+: \quad 66.9 \% \text { of } \mathrm{OP} \\
\mathrm{OA}-: 34.8 \% \text { of } \mathrm{OP}\end{array}$ \\
\hline Hart et $a l^{19}$ & $\begin{array}{l}N=979 \\
n=118\end{array}$ & - & OA+: F: $100 \%$ & \\
\hline Maddah et $a l^{24}$ & $\begin{array}{l}\mathrm{N}=625 \\
\mathrm{n}=244\end{array}$ & $\begin{array}{l}\text { OA+: } 61.2 \\
\text { OA-: } 48.0\end{array}$ & $\begin{array}{l}\text { OA+: F: } 89.8 \% \\
\text { OA-: F: } 73.8 \%\end{array}$ & \\
\hline Engström et $a \beta^{34}$ & $\begin{array}{l}\mathrm{N}=5194 \\
\mathrm{n}=209\end{array}$ & $\begin{array}{l}\mathrm{OA}+: 59.9 \\
\mathrm{OA}-: 57.6\end{array}$ & $\begin{array}{l}\text { OA+: F: } 66.5 \% \\
\text { OA-: F: } 58.4 \%\end{array}$ & $\begin{array}{l}\mathrm{OA}+: 27.9 \mathrm{~kg} / \mathrm{m}^{2} \\
\mathrm{OA}-: 25.37 \mathrm{~kg} / \mathrm{m}^{2}\end{array}$ \\
\hline Yoshimura et $\mathrm{al}^{3}$ & $\begin{array}{l}N=1690 \\
n=71\end{array}$ & $\begin{array}{l}\mathrm{OA}+: 67.3 \pm 8.2 \\
\mathrm{OA}-: 58.2 \pm 11.8\end{array}$ & $\begin{array}{l}\text { OA+: F: } 74.6 \% \\
\text { OA-: F: } 58.6 \%\end{array}$ & $\begin{array}{l}\mathrm{OA}+: 23.6 \pm 2.9 \mathrm{~kg} / \mathrm{m}^{2} \\
\mathrm{OA}-:=22.4 \pm 3.2 \mathrm{~kg} / \mathrm{m}^{2}\end{array}$ \\
\hline Nielen et $a^{54}$ & $\mathrm{~N}=175956 \mathrm{n}=4040$ & $\begin{array}{l}\text { OA+: } 69.8 \\
\text { OA-: } 51\end{array}$ & $\begin{array}{l}\text { OA+: F: } 68.7 \% \\
\text { OA-: F: } 50.4 \%\end{array}$ & - \\
\hline Marshall et al ${ }^{44}$ & $\begin{array}{l}\mathrm{N}=1076 \\
\mathrm{n}=341\end{array}$ & $O A+: 69.0$ & OA+: F: $80.4 \%$ & - \\
\hline Hussain et $a l^{37}$ & $\begin{array}{l}\mathrm{N}=20430 \\
\mathrm{n}=1222\end{array}$ & $\begin{array}{l}\text { OA+: } 68.3 \pm 7.7 \\
\text { OA-: } 64.8 \pm 8.6\end{array}$ & $\begin{array}{l}\text { OA+ : F: } 66.2 \\
\text { OA-: F: } 59.5 \%\end{array}$ & $\begin{array}{l}\mathrm{OA}+: 76.8 \% \text { of } \mathrm{OP} \\
28.6 \pm 5.0 \mathrm{~kg} / \mathrm{m}^{2} \\
\mathrm{OA}-: 62.6 \% \text { of } \mathrm{OP} \\
26.8 \pm 4.5 \mathrm{~kg} / \mathrm{m}^{2}\end{array}$ \\
\hline Sowers et $a l^{21}$ & $\begin{array}{l}N=664 \\
n=53\end{array}$ & $\begin{array}{l}\mathrm{OA}+: 50 \pm 5 \\
\mathrm{OA}-: 47 \pm 8\end{array}$ & $\begin{array}{l}\text { OA+: F: } 100 \% \\
\text { OA-: F: } 100 \%\end{array}$ & $\begin{array}{l}\mathrm{OA}+: 35.6 \pm 11.1 \mathrm{~kg} / \mathrm{m}^{2} \\
\mathrm{OA}-: 27.3 \pm 8.4 \mathrm{~kg} / \mathrm{m}^{2}\end{array}$ \\
\hline Massengale et $a l^{46}$ & $\begin{array}{l}N=2477 \\
n=466\end{array}$ & - & $\begin{array}{l}\text { OA+: F: } 58.2 \% \\
\text { OA-: F: } 46.6 \%\end{array}$ & - \\
\hline
\end{tabular}

${ }^{*}$ Data from a congress. BMI, body mass index; F, female; M, male; OA, osteoarthritis.

Table 4 Main results of prevalence of dyslipidemia and mean lipid-level values in patients with osteoarthritis (OA) and nonOA patients

\begin{tabular}{llllll}
\hline & $\begin{array}{l}\text { Prevalence of } \\
\text { dyslipidemia }\end{array}$ & $\begin{array}{l}\text { Mean CT level } \\
\text { (mg/dL) }\end{array}$ & $\begin{array}{l}\text { Mean high-density } \\
\text { lipoprotein level } \\
\text { (mg/dL) }\end{array}$ & $\begin{array}{l}\text { Mean low- } \\
\text { density lipoprotein } \\
\text { level (mg/dL) }\end{array}$ & $\begin{array}{l}\text { Mean triglyceride } \\
\text { level (mg/dL) }\end{array}$ \\
\hline OA+ population & $30.2 \% \pm 0.7 \%$ & $245 \pm 25.1$ & $54.4 \pm 8.9$ & $126.5 \pm 20.7$ & $137.3 \pm 80.3$ \\
& $n=14823$ & $n=6037$ & $n=5856$ & $n=656$ & $n=2406$ \\
OA- population & $n=28$ & $n=14$ & $n=18$ & $n=9$ & $n=15$ \\
& $8.0 \% \pm 0.1 \%$ & $233.1 \pm 17.5$ & $53.1 \pm 7.5$ & $136.9 \pm 15.9$ & $131 \pm 27.3$ \\
& $n=196168$ & $n=3763$ & $n=412$ & $n=451$ & $n=3460$ \\
& $n=13$ & $n=3$ & $n=7$ & $n=2$ & $n=6$ \\
\hline
\end{tabular}




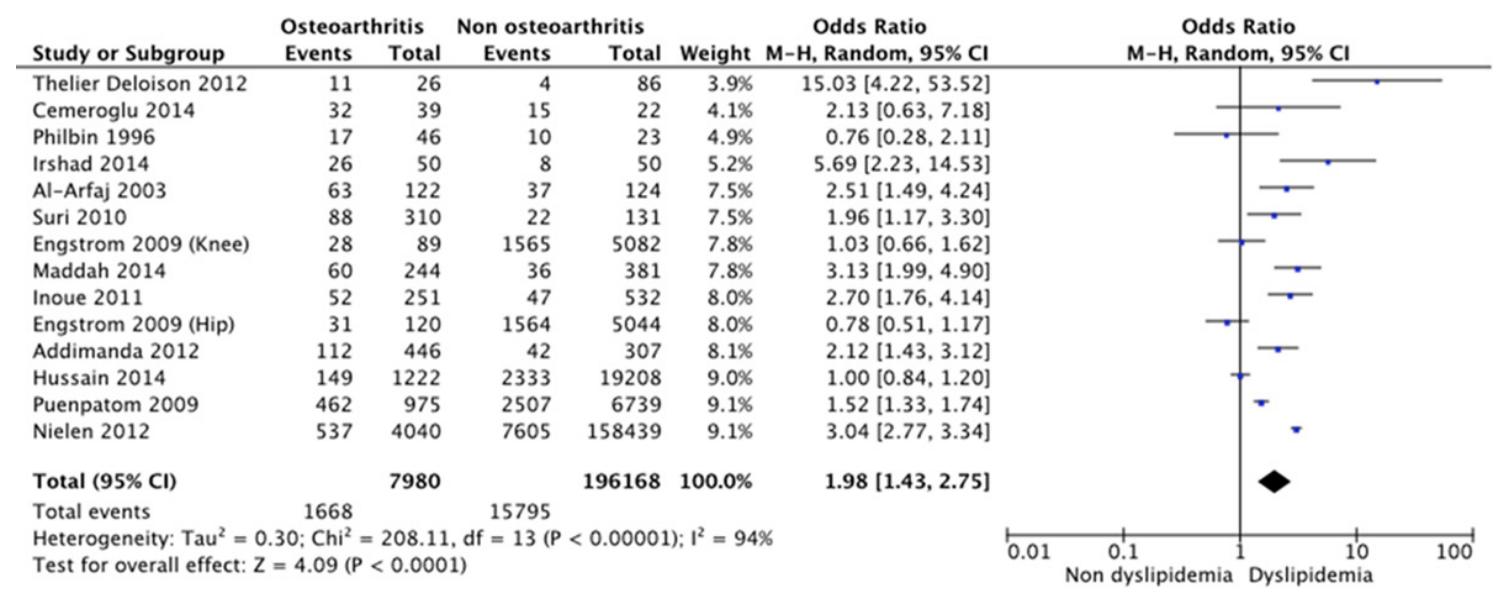

factor of development and progression of OA. Obesity increases the risk of $\mathrm{OA}$ of the weightbearing joints due to excessive mechanical stress but is also associated with dyslipidemia in MetS. ${ }^{59}$ We identified seven articles accounting for confounding factors of dyslipidemia and OA: four showed a positive association after adjustment on age and BMI. However, when we meta-analysed the seven articles that reported an age-adjusted and BMI-adjusted OR, there was no association between dyslipidemia and OA, but raw data before adjustment on age and BMI are used. Finally, the impact of statin treatment could not be assessed because of the lack of data concerning its prescription. In fact, we have no details about statin use in dyslipidemic and non-dyslipidemic patients. However, Riddle $e t$ al did not find beneficial effect of statins on the structural progress at patients monitored for a knee osteoarthritis. $^{60}$

In this funnel plot, the distribution of common values is not heterogeneous. Likewise, we can consider that there is no major publication bias in our meta-analysis.

We demonstrated an association between dyslipidemia and $\mathrm{OA}$, but the pathophysiological explanation for the causal relationship has not been clearly defined. Experimental studies suggest the existence of lipid metabolism dysfunction in OA. Mice with altered HDL metabolism showed knee OA despite abnormal weight gain. ${ }^{61}$ Gierman et al showed that dietary cholesterol intake increased spontaneous cartilage damage in mice. ${ }^{62}$ High LDL levels promote synovial inflammation and ectopic bone formation in mouse OA models. ${ }^{63}$ Oxidised-LDL (oxLDL) could be involved in the development and progression of $\mathrm{OA}$ by stimulating synovial cells (macrophages, synovial fibroblasts and endothelial cells) and chondrocytes. A treatment strategy that lowers the level of oxLDL could be interesting. ${ }^{64}$

In conclusion, this is the first systematic review and meta-analysis demonstrating an association between OA and dyslipidemia, which illustrates the role of metabolic disturbances beyond glucose metabolism in OA pathophysiology. Such a study emphasises the need to screen and manage cardiovascular comorbidities in patients with $\mathrm{OA}$ in clinical practice.

Twitter@Larhumato

Acknowledgements Laura Smales (BioMed Editing, Toronto, Canada)

Contributors PB, KL, FB and JS were involved in conception and design. PB and $\mathrm{KL}$ were involved in acquisition of data and statistical analysis. $\mathrm{PB}, \mathrm{KL}, \mathrm{CM}, \mathrm{FB}$ and JS were involved in analyses and interpretation of data, drafting of the manuscript, revision of the manuscript and final approval, had full access to all the data in the study and take responsibility for the integrity of the data and the accuracy of data analysis.

Competing interests None declared.

Provenance and peer review Not commissioned; externally peer reviewed. Data sharing statement No additional data are available.

Open Access This is an Open Access article distributed in accordance with the Creative Commons Attribution Non Commercial (CC BY-NC 4.0) license, which permits others to distribute, remix, adapt, build upon this work non-commercially, and license their derivative works on different terms, provided the original work is properly cited and the use is non-commercial. See: http://creativecommons.org/ licenses/by-nc/4.0/

(C) Article author(s) (or their employer(s) unless otherwise stated in the text of the article) 2017. All rights reserved. No commercial use is permitted unless otherwise expressly granted.

\section{REFERENCES}

1. Bijlsma JW, Berenbaum F, Lafeber FP. Osteoarthritis: an update with relevance for clinical practice. Lancet 2011;377:2115-26.

2. Mertens I, Van Gaal LF. New International Diabetes Federation (IDF) and National Cholesterol Education Program adult treatment panel III (NCEP-ATPIII) criteria and the involvement of hemostasis and fibrinolysis in the metabolic syndrome. J Thromb Haemost 2006;4:1164-6.

3. Yoshimura N, Muraki S, Oka H, et al. Accumulation of metabolic risk factors such as overweight, hypertension, Dyslipidaemia, and impaired glucose tolerance raises the risk of occurrence and progression of knee osteoarthritis: a 3-year follow-up of the ROAD study. Osteoarthritis Cartilage 2012;20:1217-26.

4. Puenpatom RA, Victor TW. Increased prevalence of metabolic syndrome in individuals with osteoarthritis: an analysis of NHANES III data. Postgrad Med 2009;121:9-20.

5. Sellam J, Berenbaum F. Is osteoarthritis a metabolic disease? Joint Bone Spine 2013;80:568-73.

6. Zhuo Q, Yang W, Chen J, et al. Metabolic syndrome meets osteoarthritis. Nat Rev Rheumatol 2012;8:729-37.

7. Yusuf E, Nelissen RG, loan-Facsinay A, et al. Association between weight or body mass index and hand osteoarthritis: a systematic review. Ann Rheum Dis 2010;69:761-5. 
8. Louati K, Vidal C, Berenbaum F, et al. Association between Diabetes mellitus and osteoarthritis: systematic literature review and metaanalysis. RMD Open 2015;1:e000077.

9. Berenbaum F. Diabetes-induced osteoarthritis: from a new paradigm to a new phenotype. Postgrad Med J 2012;88:240-2.

10. Verzijl N, Bank RA, TeKoppele JM, et al. AGEing and osteoarthritis: a different perspective. Curr Opin Rheumatol 2003;15:616-22.

11. Laiguillon MC, Courties A, Houard X, et al. Characterization of diabetic osteoarthritic cartilage and role of high glucose environment on chondrocyte activation: toward pathophysiological delineation of diabetes mellitus-related osteoarthritis. Osteoarthritis Cartilage 2015;23:1513-22.

12. Hamada D, Maynard R, Schott E, et al. Suppressive effects of insulin on tumor necrosis Factor-Dependent early osteoarthritic changes associated with obesity and type 2 Diabetes Mellitus. Arthritis Rheumatol 2016;68:1392-402.

13. Brouwers $\mathrm{H}$, von Hegedus J, Toes R, et al. Lipid mediators of inflammation in rheumatoid arthritis and osteoarthritis. Best Pract Res Clin Rheumatol 2015;29:741-55.

14. von Elm E, Altman DG, Egger M, et al. The strengthening the Reporting of Observational studies in Epidemiology (STROBE) statement: guidelines for reporting observational studies. J Clin Epidemiol 2008;61:344-9.

15. Thelier-Deloison N, Chevalier X, Oppert J-M, et al. Prevalence of clinical digital osteoarthritis (Heberden and bouchard nodes) in a selected population of patients with severe obesity: a prospective study. Osteoarthritis Cartilage 2012;20:S174-S296.

16. Soran N, Altindag O, Cakir H, et al. Assessment of paraoxonase activities in patients with knee osteoarthritis. Redox Rep 2008;13:194-8.

17. Juge $\mathrm{P}$, et al. Are metabolic factors associated with shoulder osteoartritis? A multicentric study [abstract 331]. ACR Congr 2015

18. Cheras PA, Whitaker AN, Blackwell EA, et al. Hypercoagulability and hypofibrinolysis in primary osteoarthritis. Clin Orthop Relat Res 1997:57-67.

19. Hart DJ, Doyle DV, Spector TD. Association between metabolic factors and knee osteoarthritis in women: the Chingford Study. $J$ Rheumatol 1995;22:1118-23.

20. Abourazzak F, Talbi S, Lazrak F, et al. Does metabolic syndrome or its individual components affect pain and function in knee osteoarthritis women? Curr Rheumatol Rev 2015:8-14.

21. Sowers M, Karvonen-Gutierrez CA, Palmieri-Smith R, et al. Knee osteoarthritis in obese women with cardiometabolic clustering. Arthritis Rheum 2009;61:1328-36.

22. Cemeroglu O, Aydın HI, Yasar ZS, et al. Hand and heart, hand in hand: is radiological hand osteoarthritis associated with atherosclerosis? Int J Rheum Dis 2014:17:299-303.

23. Rollefstad S, et al. Patients with Osteoarthritis DO NOT have increased risk of Cardiovascular Disease in Ullensaker Community in Norway [abstract 1274]. ACR Congr 2014.

24. Maddah S, Mahdizadeh J. Association of metabolic syndrome and its Components with Knee Osteoarthritis. Acta Med Iran 2015;53:743-8.

25. Stürmer T, Sun $Y$, Sauerland $S$, et al. Serum cholesterol and osteoarthritis. the baseline examination of the Ulm Osteoarthritis Study. J Rheumatol 1998;25:1827-32.

26. Davis MA, Ettinger WH, Neuhaus JM. The role of metabolic factors and blood pressure in the association of obesity with osteoarthritis of the knee. J Rheumatol 1988;15:1827-32.

27. Han CD, Yang IH, Lee WS, et al. Correlation between metabolic syndrome and knee osteoarthritis: data from the korean National Health and Nutrition Examination survey (KNHANES). BMC Public Health 2013;13:603.

28. Eymard F, Parsons $\mathrm{C}$, Edwards $\mathrm{MH}$, et al. Diabetes is a risk factor for knee osteoarthritis progression. Osteoarthritis Cartilage 2015;23:851-9.

29. Shea MK, Kritchevsky SB, Hsu FC, et al. The association between vitamin K status and knee osteoarthritis features in older adults: the Health, Aging and Body Composition Study. Osteoarthritis Cartilage 2015;23:370-8.

30. Inoue R, Ishibashi Y, Tsuda E, et al. Medical problems and risk factors of metabolic syndrome among radiographic knee osteoarthritis patients in the japanese general population. $J$ Orthop Sci 2011;16:704-9.

31. Al-Arfaj AS. Radiographic osteoarthritis and serum cholesterol. Saudi Med J 2003;24:745-7.

32. Nuñez $\mathrm{M}$, et al. Locus of control of pain in patients with knee osteoarthritis [abstract]. Ann Rheum Dis 2012;71:633.

33. Salaru $\mathrm{V}$, et al. The relationship between co-morbidity and quality of life in patients with knee osteoarthritis [abstract 246]. Eur J Intern Med 2013.
34. Engström G, Gerhardsson de Verdier M, Rollof J, et al. C-reactive protein, metabolic syndrome and incidence of severe hip and knee osteoarthritis. A population-based cohort study. Osteoarthritis Cartilage 2009;17:168-73.

35. Kemta Lekpa F, et al. La gonarthrose est-elle associée au syndrome métabolique ? etude transversale dans une population subsaharienne au Cameroun [abstract Di.153]. SFR Congr 2014

36. Niu J, et al. The metabolic syndrome, its elements and knee osteoarthritis : the Framingham osteoarthritis (OA) Study [abstract 949]. ACR Congr 2015.

37. Monira Hussain S, Wang Y, Cicuttini FM, et al. Incidence of total knee and hip replacement for osteoarthritis in relation to the metabolic syndrome and its components: a prospective cohort study. Semin Arthritis Rheum 2014;43:429-36.

38. Laires PA, Laíns J, Miranda LC, et al. Factors associated with inadequate pain Relief in patients with primary knee osteoarthritis in Portugal: an analysis from the survey of Osteoarthritis Real World Therapies (Sort). Value Health 2015;18:A652-A766.

39. Mishra R, Singh A, Chandra V, et al. A comparative analysis of serological parameters and oxidative stress in osteoarthritis and rheumatoid arthritis. Rheumatol Int 2012;32:2377-82.

40. Zayed HS, Younis G, Bader R, et al. Prevalence of preclinical renal dysfunction in obese egyptian patients with primary knee osteoarthritis, preliminary data. The Egyptian Rheumatologist 2013;35:239-44.

41. Dahaghin S, Bierma-Zeinstra SM, Koes BW, et al. Do metabolic factors add to the effect of overweight on hand osteoarthritis? the Rotterdam Study. Ann Rheum Dis 2007;66:916-20.

42. Haugen IK, Ramachandran VS, Misra D, et al. Hand osteoarthritis in relation to mortality and incidence of cardiovascular disease: data from the Framingham heart study. Ann Rheum Dis 2015;74:74-81.

43. Haugen IK, et al. The association between metabolic syndrome and hand osteoarthritis - Data from the Framingham Study [abstract 243]. ACR Congr 2013.

44. Marshall M, Nicholls E, Kwok WY, et al. Erosive osteoarthritis: a more severe form of radiographic hand osteoarthritis rather than a distinct entity? Ann Rheum Dis 2015;74:136-41.

45. Courties $A$, et al. La cardiopathie ischémique : une comorbidité associée à l'arthrose digitale. Résultats ancillaires de l'essai SEKOIA [abstract O.37]. SFR Congr 2014

46. Massengale M, Reichmann WM, Losina E, et al. The relationship between hand osteoarthritis and serum leptin concentration in participants of the Third National Health and Nutrition Examination Survey. Arthritis Res Ther 2012;14:R132.

47. Addimanda O, Mancarella L, Dolzani P, et al. Clinical associations in patients with hand osteoarthritis. Scand J Rheumatol 2012;41:310-3

48. Suri $\mathrm{P}, \mathrm{Katz} \mathrm{JN}$, Rainville J, et al. Vascular disease is associated with facet joint osteoarthritis. Osteoarthritis Cartilage 2010;18:1127-32.

49. Gandhi R, Woo KM, Zywiel MG, et al. Metabolic syndrome increases the prevalence of spine osteoarthritis. Orthop Surg 2014;6:23-7.

50. Šalamon L, Morović-Vergles J, Marasović-Krstulović D, et al. Differences in the prevalence and characteristics of metabolic syndrome in rheumatoid arthritis and osteoarthritis: a multicentric study. Rheumatol Int 2015;35:2047-57.

51. Meek IL, Vonkeman HE, van de Laar MA. Hyperuricaemia: a marker of increased cardiovascular risk in rheumatic patients: analysis of the ACT-CVD cohort. BMC Musculoskelet Disord 2014;15:174.

52. Oliviero F, Lo Nigro A, Bernardi D, et al. A comparative study of serum and synovial fluid lipoprotein levels in patients with various arthritides. Clin Chim Acta 2012;413:303-7.

53. Saunders FR, Yoshida K, Barr RJ, et al. Biomarkers of osteoarthritis progression. Osteoarthritis Cartilage 2013;21:S78-S312.

54. Nielen MM, van Sijl AM, Peters MJ, et al. Cardiovascular disease prevalence in patients with inflammatory arthritis, diabetes mellitus and osteoarthritis: a cross-sectional study in primary care. BMC Musculoskelet Disord 2012;13:150.

55. Philbin EF, Ries MD, Groff GD, et al. Osteoarthritis as a determinant of an adverse coronary heart disease risk profile. J Cardiovasc Risk 1996;3:529-33

56. Irshad K, Afzal MN. Comparison of serum lipid levels among patients suffering from osteoarthritis in Pakistan. Rawal Med J 2014;39:6-9.

57. Cheng K-H, Chu C-S, Lee K-T, et al. Osteoarthritis is an independent risk factor for Major adverse cardiovascular events-nationwide casecontrol studies. Eur Heart J 2013;34:P5173.

58. Visser AW, de Mutsert R, le Cessie S, et al. The relative contribution of mechanical stress and systemic processes in different types of osteoarthritis: the NEO study. Ann Rheum Dis 2015;74:1842-7.

59. Courties A, Sellam J. Obésité Et arthrose : données physiopatologiques. Rev Rhum Monogr 2016;83:18-24. 
60. Riddle DL, Moxley G, Dumenci L. Associations between statin use and changes in pain, function and structural progression: a longitudinal study of persons with knee osteoarthritis. Ann Rheum Dis 2013;72:196-203.

61. Triantaphyllidou IE, Kalyvioti E, Karavia E, et al. Perturbations in the HDL metabolic pathway predispose to the development of osteoarthritis in mice following long-term exposure to western-type diet. Osteoarthritis Cartilage 2013;21:322-30.

62. Gierman LM, Kühnast S, Koudijs A, et al. Osteoarthritis development is induced by increased dietary cholesterol and can be inhibited by atorvastatin in APOE*3leiden.CETP mice--a translational model for atherosclerosis. Ann Rheum Dis 2014;73:921-7.

63. de Munter W, van den Bosch MH, Slöetjes AW, et al. High LDL levels lead to increased synovial inflammation and accelerated ectopic bone formation during experimental osteoarthritis. Osteoarthritis Cartilage 2016;24:844-55.

64. de Munter W, van der Kraan PM, van den Berg WB, et al. High systemic levels of low-density lipoprotein cholesterol: fuel to the flames in inflammatory osteoarthritis? Rheumatology 2016;55:16-24.

65. Racaza GZ, Salido EO, Penserga EG. Clinical profile of Filipino patients with osteoarthritis seen at two arthritis clinics. Int $J$ Rheum Dis 2012;15:399-406.

66. Erb N, Pace AV, Douglas KM, et al. Risk assessment for coronary heart disease in rheumatoid arthritis and osteoarthritis. Scand $J$ Rheumatol 2004;33:293-9.

67. Shukurova S. Osteoarthritis place in rheumatic diseases hospitalization structure [abstract P-260]. MCR Congr 2014. 